\title{
Sustainable Electrodeposition of ZnO by a Galvanic Contact Method
}

\section{$\operatorname{AUTHOR}(\mathrm{S})$ :}

Shinagawa, Tsutomu; Murase, Kuniaki; Izaki, Masanobu

\section{CITATION:}

Shinagawa, Tsutomu ...[et al]. Sustainable Electrodeposition of ZnO by a Galvanic Contact Method. ELECTROCHEMICAL AND SOLID STATE LETTERS 2009, 12(9): D72-D75

ISSUE DATE:

2009

URL:

http://hdl.handle.net/2433/109929

RIGHT:

(C) 2009 The Electrochemical Society 


\title{
Sustainable Electrodeposition of $\mathrm{ZnO}$ by a Galvanic Contact
} Method

\author{
Tsutomu Shinagawa, ${ }^{\mathrm{a}, \mathrm{z}}$ Kuniaki Murase, $^{\mathrm{b}, *}$ and Masanobu Izaki ${ }^{\mathrm{c}, *}$ \\ ${ }^{a}$ Electronic Materials Research Division, Osaka Municipal Technical Research Institute, \\ Osaka 536-8553, Japan \\ ${ }^{b}$ Department of Materials Science and Engineering, Kyoto University, Kyoto 606-8501, Japan \\ ${ }^{c}$ Department of Production System Engineering, Toyohashi University of Technology, \\ Aichi 441-8580, Japan
}

\begin{abstract}
The galvanic contact deposition of $\mathrm{ZnO}$ was carried out by immersing a conductive substrate short-circuited with a $\mathrm{Zn}$ rod into $\mathrm{O}_{2}$-saturated aqueous $\mathrm{Zn}\left(\mathrm{ClO}_{4}\right)_{2}$ solutions, and the deposition behaviors were investigated in comparison with that in $\mathrm{Zn}\left(\mathrm{NO}_{3}\right)_{2}$. The dissolution of the $\mathrm{Zn}$ rod in the $\mathrm{Zn}\left(\mathrm{ClO}_{4}\right)_{2}$ solutions supplied a continuous and almost constant current to the substrate, allowing the cathodic electrodeposition of $\mathrm{ZnO}$ without an external power and by-products. The morphology of the resulting $\mathrm{ZnO}$ depended on the $\mathrm{Zn}\left(\mathrm{ClO}_{4}\right)_{2}$ concentration. In contrast, a much smaller current was observed in the $\mathrm{Zn}\left(\mathrm{NO}_{3}\right)_{2}$ solution, and little $\mathrm{ZnO}$ was deposited.
\end{abstract}

(c) 2009 The Electrochemical Society. [DOI: 10.1149/1.3168518] All rights reserved.

Manuscript submitted April 13, 2009; revised manuscript received June 12, 2009. Published July 9, 2009.

Zinc oxide $(\mathrm{ZnO})$ is an n-type semiconducting oxide with a wide bandgap energy of $3.3 \mathrm{eV}$ and a high exciton binding energy of 59 $\mathrm{meV}$, which make visible transparency and room-temperature UV emission possible. Thin $\mathrm{ZnO}$ layers including various nanostructures have received increasing attention for a wide range of applications such as chemical sensors, ${ }^{1-3}$ electrodes in solar cells, ${ }^{4-6}$ and UV emitting devices. ${ }^{7-9}$ Among the many physical and chemical processes to grow $\mathrm{ZnO}$, electrochemical deposition from aqueous solutions is a powerful technique to give high quality $\mathrm{ZnO}$ and offers a large-scale synthetic route with low cost. Since the electrodeposition technique of $\mathrm{ZnO}$ was established by Izaki and $\mathrm{Omi}^{10}$ and Peulon and Lincot in $1996,{ }^{11} \mathrm{ZnO}$ with a variety of structures, including pillar, ${ }^{12-14}$ tube, ${ }^{15,16}$ flower, ${ }^{17,18}$ and sheet, ${ }^{19}$ has been synthesized by applying the technique. Moreover, the epitaxial growth of $\mathrm{ZnO}$ has also been attained by using lattice-matched substrates. ${ }^{20-22}$ In these $\mathrm{ZnO}$ electrodepositions, cathodic electrolysis is employed in an aqueous $\mathrm{Zn}\left(\mathrm{NO}_{3}\right)_{2}$ or $\mathrm{ZnCl}_{2}$ solution, and the deposition mechanism is based on the increase in local $\mathrm{pH}$ in the vicinity of an electrode, followed by hydrolysis of zinc ions to give $\mathrm{ZnO}$

$$
\mathrm{Zn}^{2+}+2 \mathrm{OH}^{-} \rightarrow \mathrm{Zn}(\mathrm{OH})_{2} \rightarrow \mathrm{ZnO}+\mathrm{H}_{2} \mathrm{O}
$$

Such a local deposition fashion can, therefore, prevent precipitation in the bulk of solution unlike chemical bath deposition and hydrothermal synthesis. To raise the local $\mathrm{pH}$, the cathodic reduction of dissolved oxygen (DO) and nitrate ion, which gives hydroxide ion, is generally utilized

$$
\begin{gathered}
\mathrm{O}_{2}+2 \mathrm{H}_{2} \mathrm{O}+4 \mathrm{e}^{-} \rightarrow 4 \mathrm{OH}^{-} \\
\mathrm{NO}_{3}^{-}+\mathrm{H}_{2} \mathrm{O}+2 \mathrm{e}^{-} \rightarrow \mathrm{NO}_{2}^{-}+2 \mathrm{OH}^{-}
\end{gathered}
$$

and an external power, i.e., potentiostat/galvanostat, is employed to control the electrolysis.

Recently, Mondal et al. ${ }^{23}$ reported a unique electrochemical process to deposit $\mathrm{ZnO}$ without external power through a "galvanic contact method," also referred to as the "contact immersion method." In this method, a working substrate is short-circuited to an auxiliary electrode, of which the potential when immersed into the deposition bath is negative to the Nernst potential of the cathodic reaction desired on the working substrate. The galvanic contact method is, therefore, a kind of "short-circuited galvanic cell" and generally offers a "semipotentiostatic condition" without a set of potentiostat and reference electrodes. So far, metals, alloys, and metallic calcogenides, such as $\mathrm{Cu}-\mathrm{Sn},{ }^{24} \mathrm{CdTe},{ }^{25-28}$ and $\mathrm{CdSe},{ }^{29}$ have been synthesized by using galvanic contact methods. In the

\footnotetext{
* Electrochemical Society Active Member

${ }^{\text {z }}$ E-mail: tshina@omtri.city.osaka.jp
}

literature, ${ }^{23}$ a metallic zinc rod as an anode and transparent conductive oxide-coated (TCO) glass substrate as a cathode were immersed into a $10 \mathrm{mM}\left(\mathrm{M}=\mathrm{mol} \mathrm{dm}{ }^{-3}\right) \mathrm{Zn}\left(\mathrm{NO}_{3}\right)_{2}$ solution at $60-80^{\circ} \mathrm{C}$, and then the two electrodes were just short-circuited to deposit $\mathrm{ZnO}$. The driving force to promote the $\mathrm{ZnO}$ deposition is the dissolution of zinc ions from metallic zinc, which supplies electrons to the TCO glass, reducing nitrate ions. However, Mondal et al. ${ }^{23}$ reported that the growth of $\mathrm{ZnO}$ stopped at a layer thickness of $\sim 0.6 \mu \mathrm{m}$ due to the electrical resistance of $\mathrm{ZnO}$, which becomes higher with increasing thickness.

Nonetheless, this system is potentially interesting because one can obtain an external power-free solution process. Furthermore, by not using nitrate ion but using $\mathrm{DO}$ to raise the local $\mathrm{pH}$, the following overall reaction is given

$$
\mathrm{Zn}+1 / 2 \mathrm{O}_{2} \rightarrow \mathrm{ZnO}
$$

resulting in a no by-product process that keeps the $\mathrm{Zn}^{2+}$ concentration constant (Fig. 1). Therefore, the development of a galvanic contact method affording a continuous $\mathrm{ZnO}$ growth offers a useful tool to yield $\mathrm{ZnO}$. Here, we demonstrate the continuous galvanic contact deposition of $\mathrm{ZnO}$ by using simple $\mathrm{Zn}\left(\mathrm{ClO}_{4}\right)_{2}$ solutions with $\mathrm{O}_{2}$ gas bubbling, and the deposition behavior in the $\mathrm{Zn}\left(\mathrm{ClO}_{4}\right)_{2}$ solution is discussed in comparison with that in the $\mathrm{Zn}\left(\mathrm{NO}_{3}\right)_{2}$ solution.

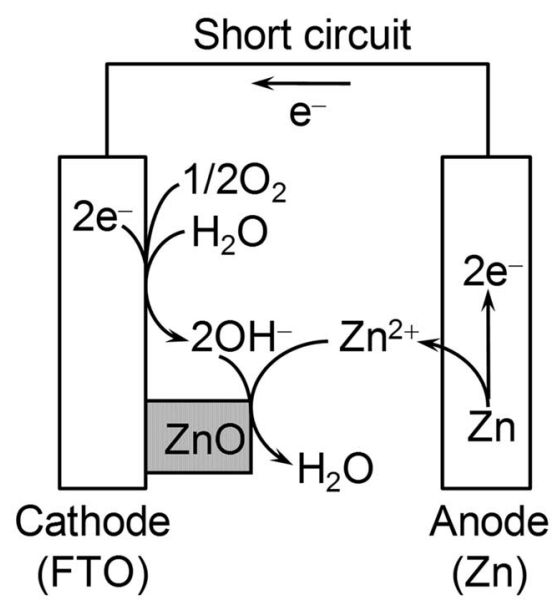

Figure 1. Schematic view of the galvanic contact deposition of $\mathrm{ZnO}$ using a Zn-bar anode immersed in an oxygenated aqueous solution. 


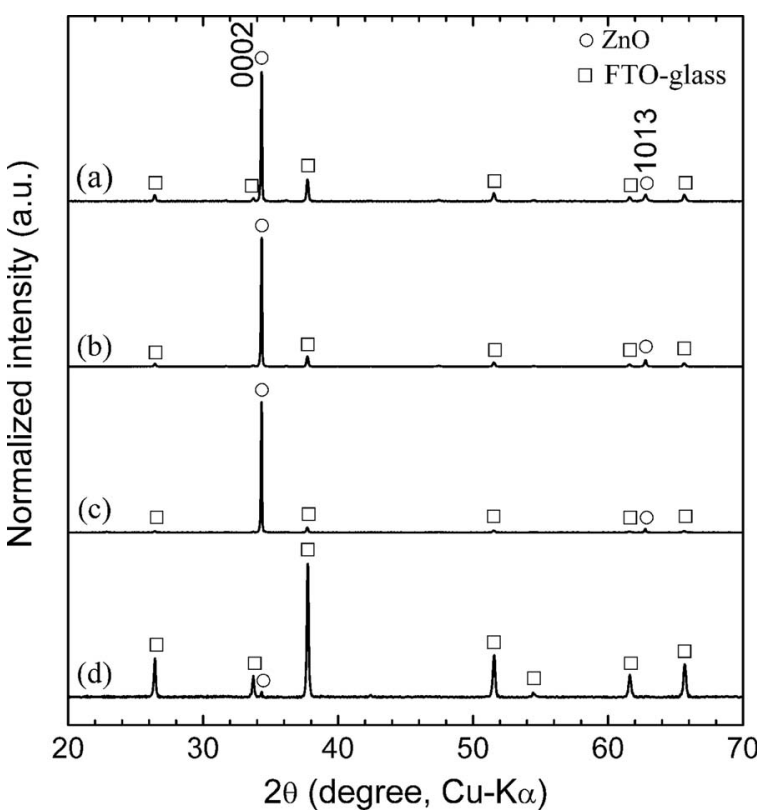

Figure 2. XRD patterns of deposits by $2 \mathrm{~h}$ galvanic contact deposition in $\mathrm{O}_{2}$-gas-bubbling solutions containing [(a)-(c)] $\mathrm{Zn}\left(\mathrm{ClO}_{4}\right)_{2}$ and (d) $\mathrm{Zn}\left(\mathrm{NO}_{3}\right)_{2}$ at $75^{\circ} \mathrm{C}$; the concentrations of $\mathrm{Zn}(\mathrm{II})$ salt are (a) 3, [(b) and (d) $] 15$, and (c) $75 \mathrm{mM}$.

\section{Experimental}

To deposit $\mathrm{ZnO}$, an aqueous solution containing 3-75 $\mathrm{mM}$ $\mathrm{Zn}\left(\mathrm{ClO}_{4}\right)_{2}$ or $15 \mathrm{mM} \mathrm{Zn}\left(\mathrm{NO}_{3}\right)_{2}$ was bubbled with $\mathrm{O}_{2}$ gas in advance for $1 \mathrm{~h}$ and heated at $75^{\circ} \mathrm{C}$. Then, a F-doped $\mathrm{SnO}_{2}$ (FTO) coated glass substrate short-circuited with a $\mathrm{Zn}$ rod was immersed into the solution for $2 \mathrm{~h}$. To prepare the solutions, reagent grade chemicals of $\mathrm{Zn}\left(\mathrm{ClO}_{4}\right)_{2} \cdot 6 \mathrm{H}_{2} \mathrm{O}$ (Sigma-Aldrich, Inc.) and $\mathrm{Zn}\left(\mathrm{NO}_{3}\right)_{2} \cdot 6 \mathrm{H}_{2} \mathrm{O}$ (Nacalai Tesque, Inc.) and deionized water purified by a Milli RX12 Plus system were employed. The $\mathrm{pH}$ of the solutions were 5.3 and 5.4 for $\mathrm{Zn}\left(\mathrm{ClO}_{4}\right)_{2}$ and $\mathrm{Zn}\left(\mathrm{NO}_{3}\right)_{2}$, respectively, at $25^{\circ} \mathrm{C}$. The FTO glass used was $30 \times 10 \times 1.1 \mathrm{~mm}$ with a $9 \Omega$ sheet resistance (Asahi Glass Co., Ltd.), and the $\mathrm{Zn}$ rod used was a guaranteed reagent and $\phi 8 \times 60 \mathrm{~mm}$ (Kanto Chemical Co., Inc.). During the immersion, $\mathrm{O}_{2}$ gas bubbling at a flow rate of $10 \mathrm{~cm}^{3} \mathrm{~min}^{-1}$ was carried out continuously, and the solution was thermostatted at $75^{\circ} \mathrm{C}$. After the immersion, the deposit on the FTO glass was rinsed with deionized water and dried under ambient atmosphere. The characterization was performed with an X-ray diffractometer (XRD, Rigaku RINT2500) and a field-emissionscanning electron microscope (FESEM, JEOL JSM6700F).

The current and electrode potential during the immersion were measured with a digital multimeter (Yokogawa 7552) and a doublejunction-type $\mathrm{Ag} / \mathrm{AgCl}$ reference electrode (DKK-TOA HS-305D). The double-junction electrode was composed of an inner $(\mathrm{Ag} / \mathrm{AgCl}$ electrode immersed in a saturated $\mathrm{KCl}$ solution) and an outer compartment divided by a glass frit. To prevent the precipitation of low solubility $\mathrm{KClO}_{4}$ at the solution junction, the outer compartment was filled with a $10 \mathrm{wt} \% \mathrm{NaCl}$ aqueous solution.

Linear sweep voltammetry (LSV) was carried out using an automatic polarization system (Hokuto Denko HSV-100) and a Pt-sheet counter electrode. The LSV was started from each steady rest potential at a sweep rate of $5 \mathrm{mV} \mathrm{s}^{-1}$.

\section{Results and Discussion}

Figure 2 shows normalized XRD patterns of deposits by $2 \mathrm{~h}$ galvanic contact deposition from the 3,15 , and $75 \mathrm{mM} \mathrm{Zn}\left(\mathrm{ClO}_{4}\right)_{2}$ and $15 \mathrm{mM} \mathrm{Zn}\left(\mathrm{NO}_{3}\right)_{2}$ solutions. All deposits obtained from the $\mathrm{Zn}\left(\mathrm{ClO}_{4}\right)_{2}$ solutions were identified as $c$-axis-oriented $\mathrm{ZnO}$ with a
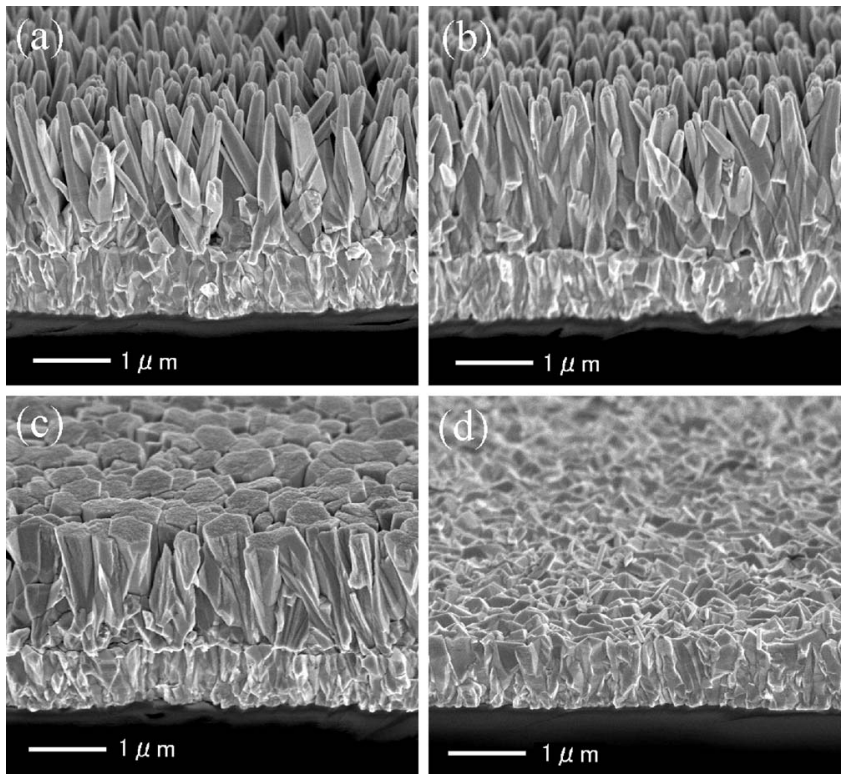

Figure 3. Tilted FESEM images of deposits by $2 \mathrm{~h}$ galvanic contact deposition in $\mathrm{O}_{2}$-gas-bubbling solutions containing [(a)-(c)] $\mathrm{Zn}\left(\mathrm{ClO}_{4}\right)_{2}$ and (d) $\mathrm{Zn}\left(\mathrm{NO}_{3}\right)_{2}$ at $75^{\circ} \mathrm{C}$; the concentrations of $\mathrm{Zn}$ (II) salt are (a) 3, [(b) and (d)] 15 , and (c) $75 \mathrm{mM}$.

wurtzite structure (JCPDS no. 36-1451), and no other phases such as zinc hydroxides and metallic zinc were recognized. In the pattern for the $\mathrm{Zn}\left(\mathrm{NO}_{3}\right)_{2}$ solution (Fig. 2d), only a slight peak assignable to $\mathrm{ZnO} 0002$ was observed in addition to strong diffractions from the FTO glass substrate. Figure 3 shows FESEM images of the deposits corresponding to Fig. 2. Whereas dense $\mathrm{ZnO}$ nanopillars of $2-2.5 \mu \mathrm{m}$ length and $0.15-0.3 \mu \mathrm{m}$ diameter were observed after the galvanic contact deposition using 3 and $15 \mathrm{mM} \mathrm{Zn}\left(\mathrm{ClO}_{4}\right)_{2}$ solutions, a $1.6 \mu \mathrm{m}$ thick $\mathrm{ZnO}$ layer composed of hexagonal columnar grains with a diameter of about $0.5 \mu \mathrm{m}$ grew from the $75 \mathrm{mM}$ $\mathrm{Zn}\left(\mathrm{ClO}_{4}\right)_{2}$ solution. Such $\mathrm{Zn}^{2+}$-concentration-dependent morphology change in electrodeposited $\mathrm{ZnO}$ has been reported elsewhere. ${ }^{11,13,14}$ In contrast, considerably sparse and small $\mathrm{ZnO}$ grains of about $0.3 \mu \mathrm{m}$ length and $50 \mathrm{~nm}$ diameter were seen in the deposit from the $15 \mathrm{mM} \mathrm{Zn}\left(\mathrm{NO}_{3}\right)_{2}$ solution. These results clearly indicate that the galvanic contact method using the $\mathrm{Zn}\left(\mathrm{ClO}_{4}\right)_{2}$ solutions enables the continuous growth of $\mathrm{ZnO}$ beyond the thickness limit of $\sim 0.6 \mu \mathrm{m}$ reported by Mondal et al. ${ }^{23}$

The deposition behavior of $\mathrm{ZnO}$, including current density and electrode potential, during the galvanic contact deposition is shown in Fig. 4. The rest potentials of an FTO glass in the $\mathrm{Zn}\left(\mathrm{ClO}_{4}\right)_{2}$ and $\mathrm{Zn}\left(\mathrm{NO}_{3}\right)_{2}$ solutions were $0.2-0.4$ and $0.07 \mathrm{~V}$ (vs $\mathrm{Ag} / \mathrm{AgCl}$ ), respectively, and then dropped sharply to -0.95 and $-0.62 \mathrm{~V}$ immediately
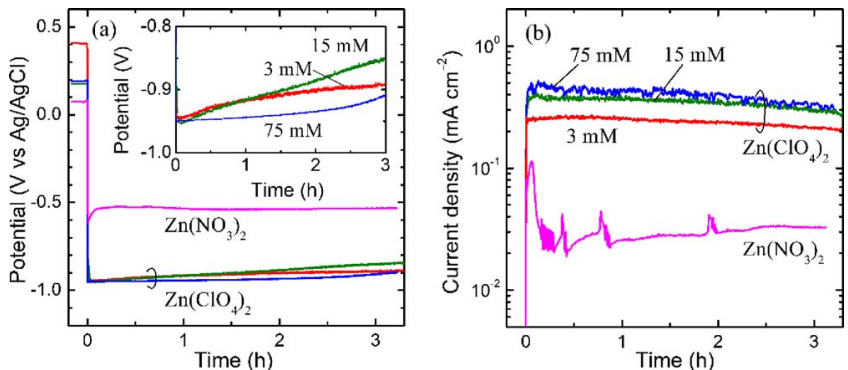

Figure 4. (Color online) Variation of (a) potential and (b) current density of an FTO glass substrate short-circuited with a $\mathrm{Zn}$ rod during galvanic contact deposition. 


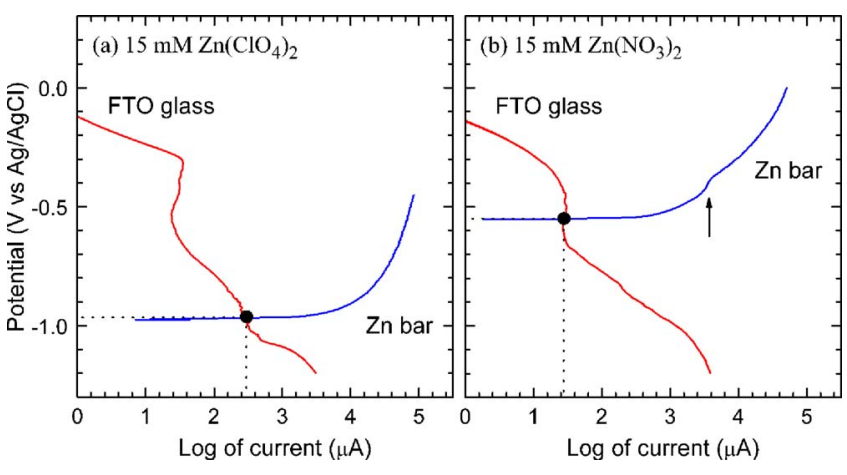

Figure 5. (Color online) LSV curves: electrode potentials of an FTO glass substrate and a $\mathrm{Zn}$ rod vs logarithm of current in (a) $15 \mathrm{mM} \mathrm{Zn}\left(\mathrm{ClO}_{4}\right)_{2}$ and (b) $15 \mathrm{mM} \mathrm{Zn}\left(\mathrm{NO}_{3}\right)_{2}$ solutions.

after the short circuiting. This value $(-0.95 \mathrm{~V})$ for the $\mathrm{Zn}\left(\mathrm{ClO}_{4}\right)_{2}$ solution was close to the standard electrode potential of $\mathrm{Zn}^{2+} / \mathrm{Zn}$ $\left(E^{0}=-0.96 \mathrm{~V} \text { vs } \mathrm{Ag} / \mathrm{AgCl}\right)^{30}$ and then slightly and gradually drifted $40-100 \mathrm{mV}$ within $3 \mathrm{~h}$. In contrast, the cathode potential in the $\mathrm{Zn}\left(\mathrm{NO}_{3}\right)_{2}$ solution shifted positively within $10 \mathrm{~min}$ and remained at a constant value of $-0.53 \mathrm{~V}$ for at least $3 \mathrm{~h}$. In the variation in the current density (Fig. 4b), it was seen that the currents for the $\mathrm{Zn}\left(\mathrm{ClO}_{4}\right)_{2}$ and $\mathrm{Zn}\left(\mathrm{NO}_{3}\right)_{2}$ solutions differed by 1 order of magnitude. The current density in the $\mathrm{Zn}\left(\mathrm{ClO}_{4}\right)_{2}$ solution was kept at almost constant values ranging from 0.2 to $0.5 \mathrm{~mA} \mathrm{~cm}{ }^{-2}$ up to at least $3 \mathrm{~h}$ with a $\mathrm{Zn}^{2+}$ concentration dependence. This indicates that the stable and continuous dissolution of the $\mathrm{Zn}^{2+}$ ion from the $\mathrm{Zn}$ rod, which supplies electrons to an FTO glass, takes place spontaneously in the $\mathrm{Zn}\left(\mathrm{ClO}_{4}\right)_{2}$ solutions.

To investigate the origin of these differences between the two types of solution, LSV was performed cathodically on an FTO glass and anodically on a $\mathrm{Zn}$ rod in an $\mathrm{O}_{2}$-gas-bubbling solution containing $15 \mathrm{mM} \mathrm{Zn}\left(\mathrm{ClO}_{4}\right)_{2}$ or $\mathrm{Zn}\left(\mathrm{NO}_{3}\right)_{2}$ at a sweep rate of $5 \mathrm{mV} \mathrm{s}^{-1}$. The potential applied to the electrode was plotted against the logarithm of the detected current, as shown in Fig. 5. The polarization curves for an FTO glass were similar irrespective of the solution type. The current derived from the DO reduction emerged at potentials at around $-0.6 \mathrm{~V}$, and the reduction of $\mathrm{Zn}^{2+}$ ions took place at potentials below $-1.1 \mathrm{~V}$. In contrast, there is a considerable difference in the polarization curves for the $\mathrm{Zn}$ rod. The rest potential of the $\mathrm{Zn}$ rod in the $\mathrm{Zn}\left(\mathrm{ClO}_{4}\right)_{2}$ solution was $0.4 \mathrm{~V}$ negative to that in the $\mathrm{Zn}\left(\mathrm{NO}_{3}\right)_{2}$ solution, which is near the value of $E^{0}\left(\mathrm{Zn}^{2+} / \mathrm{Zn}\right)$. When two electrodes are short-circuited, the electrical current and potential between the electrodes naturally become almost equal. Therefore, the intersection of two curves in Fig. 5, i.e., the cathodic curve for an FTO glass and the anodic curve for a $\mathrm{Zn}$ rod, should signify the short-circuit condition in each solution. Indeed, the electrical current and potential values pointed by the intersections agreed well with the values under the galvanic contact deposition (Fig. 4). Because the potential at each intersection is close to each rest potential of a $\mathrm{Zn}$ rod, the difference in the galvanic contact deposition behavior in Fig. 4 may well be dominated by the rest potential of a $\mathrm{Zn}$ rod.

The time variation of the $\mathrm{Zn}$-rod rest potential in $0.1 \mathrm{M} \mathrm{NaClO}_{4}$ solutions with varying $\mathrm{NaNO}_{3}$ concentrations was measured to confirm the influence of the $\mathrm{NO}_{3}^{-}$ion, as shown in Fig. 6. Whereas the $\mathrm{Zn}$ rod immersed into the $\mathrm{NaClO}_{4}$ solution without $\mathrm{NO}_{3}^{-}$exhibited a constant potential close to $E^{0}\left(\mathrm{Zn}^{2+} / \mathrm{Zn}\right)$, the rest potential of the $\mathrm{Zn}$ rod immersed in the solutions containing $\mathrm{NO}_{3}^{-}$readily shifted positively and was kept at an almost constant value. The potential shift variation increased with an increasing concentration of $\mathrm{NO}_{3}^{-}$, indicating that the chemical state of the $\mathrm{Zn}$-rod surface changes in the presence of $\mathrm{NO}_{3}^{-}$. Some precipitates, i.e., corrosion products, involv-

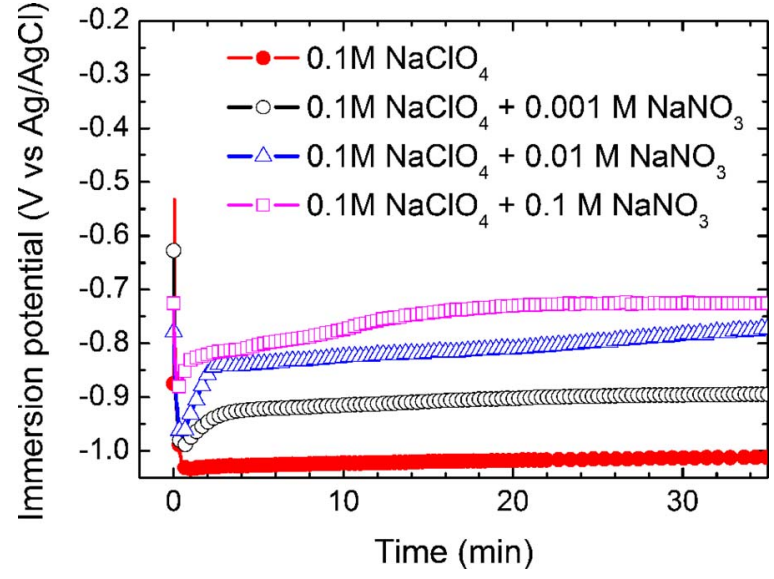

Figure 6. (Color online) Variation in the immersion potential of a $\mathrm{Zn}$ rod in $0.1 \mathrm{M} \mathrm{NaClO}_{4}$ solutions with and without $\mathrm{NaNO}_{3}$.

ing $\mathrm{NO}_{3}^{-}$would be formed on the $\mathrm{Zn}$-rod surface. A plateau assignable to the dissolution was recognized in the LSV of the $\mathrm{Zn}$ rod, as shown by an arrow in Fig. 5b.

\section{Conclusions}

We have developed a synthetic method to yield $\mathrm{ZnO}$ based on the simple immersion of a conductive substrate short-circuited with a metallic zinc into $\mathrm{Zn}\left(\mathrm{ClO}_{4}\right)_{2}$ aqueous solutions bubbled with $\mathrm{O}_{2}$ gas and have also revealed the negative influence of the $\mathrm{NO}_{3}^{-}$ion. Using the $\mathrm{Zn}\left(\mathrm{ClO}_{4}\right)_{2}$ solution made an external power-free and byproduct-free process possible. This galvanic contact method offers great potential for the external power-free electrodeposition technique of oxides.

\section{Acknowledgment}

This work was supported by a grant-in-aid for Encouragement of Young Scientists (B) from the Ministry of Education, Culture, Sports, Science and Technology of Japan.

T. Shinagawa assisted in meeting the publication costs of this article.

\section{References}

1. S. Polarz, A. Roy, M. Lehmann, M. Driess, F. E. Kruis, A. Hoffmann, and P. Zimmer, Adv. Funct. Mater., 17, 1385 (2007).

2. H.-W. Ra, K.-S. Choi, J.-H. Kim, Y.-B. Hahn, and Y.-H. Im, Small, 4, 1105 (2008)

3. V. Kobrinsky, A. Rothschild, V. Lumelsky, Y. Komen, and Y. Lifshitz, Appl. Phys. Lett., 93, 113502 (2008)

4. M. Law, L. E. Greene, J. C. Johnson, R. Saykally, and P. Yang, Nature Mater, 4, 455 (2005)

5. J. B. Baxter and E. S. Aydil, Appl. Phys. Lett., 86, 053114 (2005).

6. T. P. Chou, Q. Zhang, G. E. Fryxell, and G. Z. Cao, Adv. Mater. (Weinheim, Ger.), 19, 2588 (2007).

7. M. H. Huang, S. Mao, H. Feick, H. Yan, Y. Wu, H. Kind, E. Weber, R. Russo, and P. Yang, Science, 292, 1897 (2001).

8. R. Könenkamp, R. C. Word, and C. Schlegel, Appl. Phys. Lett., 85, 6004 (2004)

9. J.-H. Lim, C.-K. Kang, K.-K. Kim, I.-K. Park, D.-K. Hwang, and S.-J. Park, $A d v$. Mater. (Weinheim, Ger.), 18, 2720 (2006).

10. M. Izaki and T. Omi, Appl. Phys. Lett., 68, 2439 (1996).

11. S. Peulon and D. Lincot, Adv. Mater. (Weinheim, Ger.), 8, 166 (1996).

12. M. Lai and D. J. Riley, Chem. Mater, 18, 2233 (2006).

13. M. Izaki, T. Shinagawa, and H. Takahashi, J. Phys. D: Appl. Phys., 39, 1481 (2006)

14. J. Elias, R. Tena-Zaera, and C. Lévy-Clément, J. Electroanal. Chem., 621, 171 (2008).

15. L. Vayssieres, K. Keis, A. Hagfeldt, and S.-E. Lindquist, Chem. Mater, 13, 4395 (2001).

16. D. Lincot, Thin Solid Films, 487, 40 (2005).

17. M. Watanabe, H. Aritomo, I. Yamaguchi, T. Shinagawa, T. Tamai, A. Tasaka, and M. Izaki, Chem. Lett., 36, 680 (2007).

18. M. Izaki, M. Watanabe, H. Aritomo, I. Yamaguchi, S. Asahina, T. Shinagawa, M Chigane, M. Inaba, and A. Tasaka, Cryst. Growth Des., 8, 1418 (2008).

19. D. Pradhan and K. T. Leung, Langmuir, 24, 9707 (2008).

20. T. Pauporte and D. Lincot, Appl. Phys. Lett., 75, 3817 (1999).

21. R. Liu, A. A. Vertegel, E. W. Bohannan, T. A. Sorenson, and J. A. Switzer, Chem. 
Mater, 13, 508 (2001).

22. M. Izaki, S. Watase, and H. Takahashi, Adv. Mater. (Weinheim, Ger.), 15, 2000 (2003).

23. A. Mondal, N. Mukherjee, and S. K. Bhar, Mater. Lett., 60, 1748 (2006).

24. Y. Fujiwara, Thin Solid Films, 425, 121 (2003).

25. T. Katase, R. Kurosaki, K. Murase, T. Hirato, and Y. Awakura, Electrochem. SolidState Lett., 9, C69 (2006).

26. R. N. Bhattacharya and K. Rajeshwar, J. Electrochem. Soc., 131, 939 (1984).
27. K. Arai, S. Hagiwara, K. Murase, T. Hirato, and Y. Awakura, J. Electrochem. Soc., 152, C237 (2005).

28. K. Arai, S. Hagiwara, S. Takayama, K. Murase, T. Hirato, and Y. Awakura, Electrochem. Commun., 8, 605 (2006).

29. K. R. Murali, I. Radhakrishna, K. N. Rao, and V. K. Venkatesan, J. Mater. Sci., 25, 3521 (1990).

30. M. Pourbaix, Atlas of Electrochemical Equilibria in Aqueos Solutions, NACE, Houston, TX (1974). 